\title{
Samuel Becket's Waiting for Godot: Revolutionizing Conventional Theatre and Redefining Norms
}

\author{
Dr. Shreeja Tripathi Sharma
}

Assistant Professor

Department of English

Institute for Excellence in Higher Education

Bhopal, M.P, India

shreeja.sharma@gmail.com

\begin{abstract}
Samuel Beckett's play Waiting for Godot revolutionized the conventional theatre and redefined norms which shaped twentieth century drama. The play launched an absurdist style of writing on the landscape of drama which gave the life of performance to the intellectual existentialist ideals of Soren Aabaye Kierkegaard's and Jean-Paul Sartre's philosophy. This research paper analyses the elements of Existentialism with respect to supportive evidence from the play.
\end{abstract}

Keywords: Samuel Beckett, Waiting for Godot, Existentialism, Theatre of the Absurd

Samuel Beckett's play Waiting for Godot has been a milestone in history of twentieth century drama. The play revolutionized the contemporary theatre and cast a profound influence on generations of succeeding dramatists. Beckett's mysterious 'tragicomedy' raised the curious question: Who is Godot?

Becket had discarded the conventions of drama and set the foundation of what would later be termed "Theatre of the Absurd," by Martin Esslin. The lack of action, dialogue, spectacle and the sense of overwhelming, over-arching meaningless typified in the 
play became the code of playwrights who followed. Beckett exposed the universal misery of the modern man though his iconic absurd imagery - a bare tree, a desolate landscape, two tramps, a master and a slave - metaphors who silently sobbed and depicted the suffering of a yearning civilization waiting for apparently for a cold and distant Godot.

Beckett's play has been scrutinized for traces of existentialist philosophy time and again by critics, a philosophy identified most closely with Jean Paul Sartre. Beckett presents conflict between living according to spiritual belief in the essence of life, in contrast to living by the existential philosophy, which upholds that it is up to the individual to discover the meaning of life through personal experience in the earthly world.

Existentialism, an intellectual movement, emerged after the World-War II owing much of its genesis to the inadequacy of reason to explain human existence. It influenced the Theatre of the Absurd, a trend in drama characterized by experimental techniques and nihilism.

The theory was developed by thinkers including Soren Aabaye Kierkegaard, Jean Paul Sartre and Martin Heidegger and gave forth the view that human beings live in a socalled meaningless universe and have no purpose behind their life.

Existentialism repudiates the doctrine of Essentialism which acknowledges the primacy of essence. Existentialism holds that human beings live under absurd circumstances, which are forced upon them by an unknown force and undergo mental pains and sufferings. The doctrine asserts that the reason behind sufferings of human beings is not the terrible world but the fact that they are living freely in it. Further, the human beings are free to choose for themselves and that even not making a choice is a choice. To put it simply, existentialism believes that "man is what he does".

Most traditional plays begin with some action or event which leads to a dramatic conflict. However, no movement takes place in Waiting for Godot, and the entire play is 
about an abstract struggle involving the passage of time. Vladimir and Estragon, two tramps known to one another by nicknames Didi and Gogo, wait on a desolate plain by a tree to keep an appointment with someone called Godot. Dressed in the rags and bowler hats they play games to pass the time and discuss such subjects as Christianity, the monotonous process of waiting and the possibility of escaping their situation by committing suicide. Metaphorically, the pair is regarded as body and mind with Vladimir functioning as intellect and Estragon as the physical half.

The tramps soon encounter Pozzo, a determined man who drives his withered and debased slave Lucky forward with a whip. Pozzo and Lucky depart, and the first act concludes as a messenger informs Vladimir and Estragon that Godot will not arrive today, but probably tomorrow.

The second act, the latter half of Waiting for Godot is essentially a recapitulation of the first. The characters seem largely unaware that they are repeating their previous action, a reflection of a stagnant process of waiting. Pozzo and Lucky return in the second act transformed by time: Pozzo is blind and Lucky is mute. Vladimir and Estragon are again informed that Godot will not arrive today, but probably tomorrow. The play concludes as it began, with the two tramps waiting for Godot.

The elements of existentialism can be explored in the play. The theory of Existentialism asserts that people waste their lives by remaining inactive and wait for the God to redeem them by the promised salvation. However, Existentialism questions the religious particularly Christian belief in God and even questions the existence of God. The existentialists argue that humans must break the habit of expecting salvation, and take matters into their own hands in order to bring meaning into their lives.

Inaction is the most striking element of Waiting for Godot, as Estragon says “Nothing happens, nobody comes, nobody goes, it’s awful." (35). Estragon's refrain 
"Nothing to be done" is repeated several times in the play Many times, Estragon says "Let's go", but Vladimir always reminds him that they can't as they are "waiting for Godot" (66). Whenever Estragon and Vladimir make a decision, the stage directions dictate that "They do not move". Their inability to act renders Vladimir and Estragon unable to determine their own fates. Instead of acting, they can only wait for someone or something to act upon them.

Existentialism suggests that life has no intrinsic meaning or value. According to this view, individuals or even the entire human species is insignificant, without purpose and unlikely to change in the totality of existence. Each individual is an isolated being born into the universe, barred from knowing the 'why' or the reason for his existence. The inherent meaninglessness of life is largely explored and consequently leads one to potentially create their own subjective 'meaning' or 'purpose'.

Waiting for Godot portrays the struggle of life through the experience of the two tramps. It is useless fight in the struggle of life, because the outcome of life will always remain the same - death. Several lines like - there is "No use struggling", as "One is what one is", since the "essential doesn't change" reverberate this idea. Their actions and ideas are meaningless - When talking about suicide, Vladimir and Estragon decide not to "do anything. It's safer" (11).

The theory of Existentialism argues that no one is there to answer the question of human existence in this world. Moreover, our Freewill, freedom and choices initiate us towards the journey of looking for meaning in the complex riddle of our life - the search of meaning in the meaningless existence. The extent to which a free person is truly free and the scope of Freewill itself is ironically limited.

Similar ideas are reflected in the play where Estragon and Vladimir are waiting for Godot to reveal the true purpose of their lives. Besides, we see that Estragon and Vladimir are living a miserable life, not because life is the name of pains but rather just as they are 
free. The play thus runs with the undercurrents of conflict between destiny and free will.

Lucky who is a slave and does not have freedom and choices is contented and satisfied with his life as compared to Estragon and Vladimir. Though his life is tough yet he does not consider it tough. A purpose has been set for him by his master. On the other hand, Estragon and Vladimir have no purpose. No one has an exact answer of their question. It would have been easier for them if they had a Master. Freewill is thus their paradoxical problem.

Existentialism is closely associated with nihilism, a belief which suggests that all values are baseless and that nothing can be known or communicated. It is often regarded as an extreme form of pessimism, which condemns the concept of existence.

The play Waiting for Godot starts with nothingness and ends with nothingness. The two tramps do nothing, even then they are doing something. "Waiting for Godot" presents a situation that has no begging and no end. Tramps don't know about their past nor are they sure about their future. The two tramps seem to surrender nihilistically at one point, apparently, to end their sufferings: "Vladimir: we'll hang ourselves tomorrow. (Pause.) Unless Godot comes."

The undercurrent of despair runs through the play. Vladimir and Estragon have nothing significant to do with their lives other than wait for Godot. The hopeless plight of the tramps while waiting for the unknown man draws an analogy to the plight of the suffering mankind yearning for salvation.

Man has been waiting and searching constantly to make sense out his life. The shadow of despair runs in the play and the pessimistic world of the two tramps is reflected at several places such as in the lines:

“Estragon: Let's go.

Vladimir: We can't. 


\section{Estragon: Why not?}

Vladimir: We're waiting for Godot."

The strains of Existentialism run in the play, where literally "nothing happens", the play begins with inaction and ends with inaction. The play portrays the struggle of life through the experience of the two tramps who keep waiting for Godot, but the meaning of the play, like the meaning of human existence remains unclear. The freedom and choice which Vladimir and Estragon have, unlike the slave Lucky, paradoxically becomes the reason for their suffering as it propels them to search for meaning of existence, which remains fleeting and inaccessible. The undercurrents of despair and nihilism is evident in the play. It can be concluded that the play is an artistic portrayal of the theory of Existentialism. 


\section{Bibliography}

Becket Samuel. Waiting for Godot. A Tragicomedy in two Acts. Kolkata: Booksway, 2016.

Blackman, H. J. Six existentialist thinkers. London: Routledge \& Kegan Paul Ltd.1952.

Bloom, Harold. Albert Camus's The Stranger Bloom's Guides Comprehensive Research and Study Guides. New York: Infobase Publishing, 2008. Pdf.

Sartre, J. P., and Mairet, P. Existentialism is a Humanism. New Haven: Yale University Press, 1960.Pdf. 